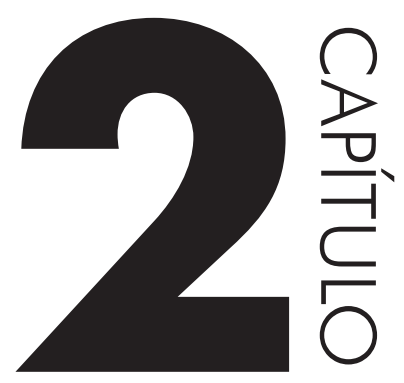

\title{
MODELAGEM 3D REALISTA E IMERSÃO
}

O seu foco determina a sua realidade.

Mestre Qui-Gon Jinn

Em 25 de maio de 1977 era iniciada uma das maiores revoluções em termos de técnica da indústria cinematográfica. O público e a crítica assistiam a estreia do filme Star Wars: Uma nova esperança, primeiro filme da franquia de George Lucas. Os produtores e críticos da época estavam céticos em relação ao produto final a ser apresentado pelo jovem diretor, que filmara em três locais diferentes (Tunísia, Inglaterra e Guatemala) e contara com um orçamento apertado.

Muitos dos técnicos de produção, ainda durante as filmagens em Londres, questionavam os produtores americanos "que filme era aquele, com tantas baba- 
quices e coisas sem sentido", pois o épico espacial idealizado por Lucas ia na contramão das produções da época, mas ia de encontro com um público jovem, leitor de ficção cientifica e de quadrinhos. O universo fantástico de Asimov, Herbert e Wells agora ganhava um novo componente, que conquistava o público não apenas pelo seu universo fantástico, mas pela narrativa política social construída através das relações apresentadas por jogos de poder.

A necessidade de efeitos visuais, para a construção da narrativa cinematográfica datam dos primórdios do cinema. Georges Méliès, autor de mais de 500 filmes, e criador do primeiro estúdio cinematográfico da Europa, é considerado o patrono dessa arte, que torna real o imaginário, quando na produção de filmes como Viagem à Lua e $\mathrm{O}$ Reino das Fadas, adapta técnicas amplamente utilizadas no teatro para criar ilusões espaciais, além da utilização da edição de imagens, posicionamento de câmeras, da criação do storyboard, utilização de maquetes, além de pintar suas obras, para que as mesmas fossem apresentadas coloridas, e assim, gerar veracidade as estórias apresentadas, mas, é com o início da saga Star Wars que surge a inserção de elementos gráficos digitais para garantir a veracidade da ilusão imagética apresentada.

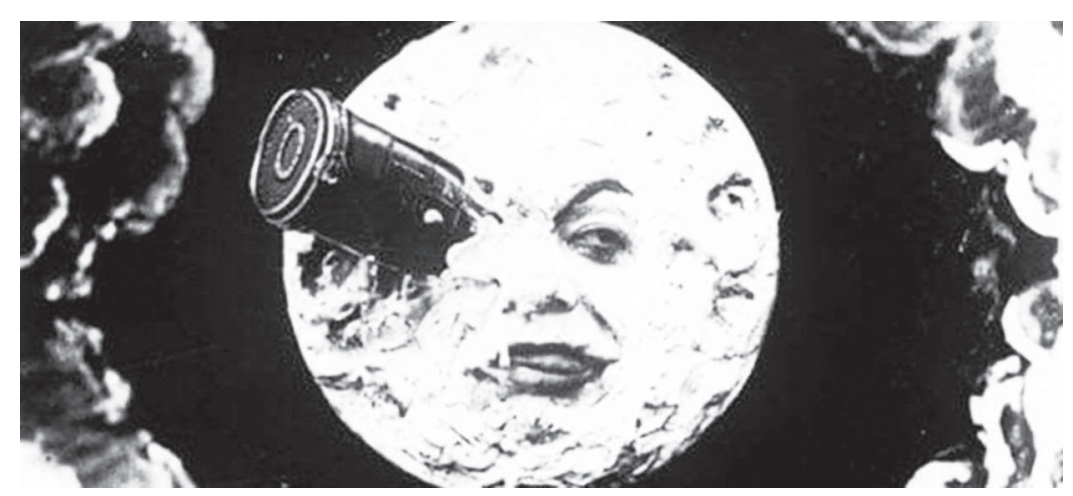

Figura 2.1. Imagem do filme Viagem a Lua, de Georges Méliès (1902).

O universo diatópico, idealizado por George Lucas e Ralph MacQuarrie, é agente detentor de protagonismo durante a narrativa. $\mathrm{O}$ deserto de Tatooine, a cidade Imperial de Alderaan, o Senado da República, são locais que desempenham papéis na trama, e trazem consigo uma carga de significações. O universo ficcional agora ganha em possibilidade de movimentos, as ações dos personagens, seus movimentos e suas relações com outros personagens e, os ambientes agora apresentam novas possibilidades narrativas. 
Para além do aspecto visual da trama, Star Wars apresenta uma estória intrinsecamente política, com situações que facilmente poderiam ser encontradas no dia-a-dia do expectador, o que permite uma identificação por parte deste, e que enseja um olhar mais profundo sob questões como as relações sociais e suas implicações quanto ao sujeito, as relações comerciais entre estados, a corrupção, o amor, a religião, e em última instância, ao próprio indivíduo. Dito isto, podemos perceber de que forma a indústria de entretenimento passou a perceber as inúmeras possibilidades estéticas a partir deste fenômeno. O digital passa agora a exercer função de ferramenta de aprimoramento dos efeitos visuais através do advento das técnicas gráficas tridimensionais. O que antes só era possível através da construção de maquetes e miniaturas, agora ganha novas formas e aceleram o processo de produção por meio do computador.

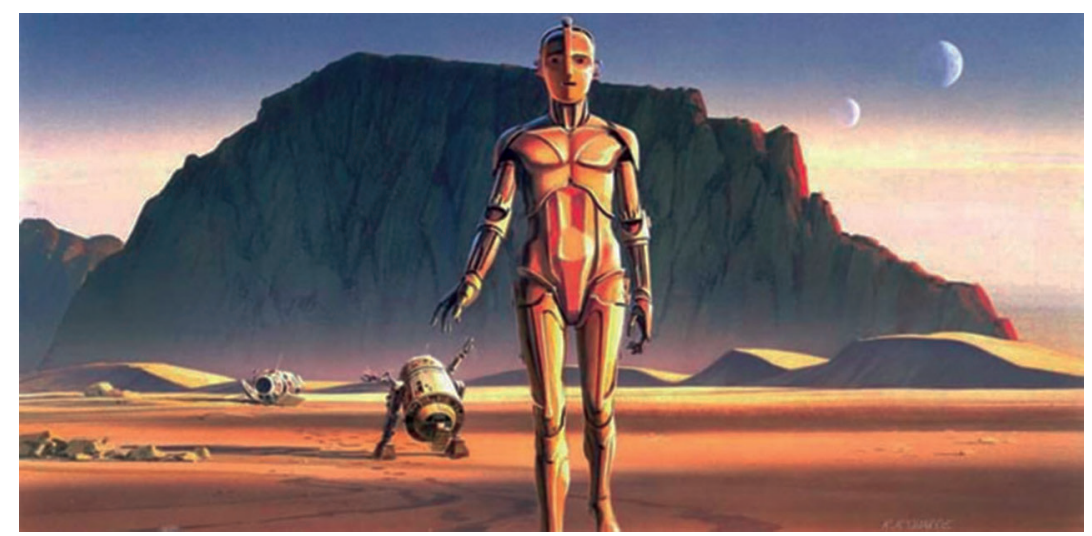

Figura 2.2. Concept Art para o filme Star Wars, de Raplh MacQuarrie (1975).

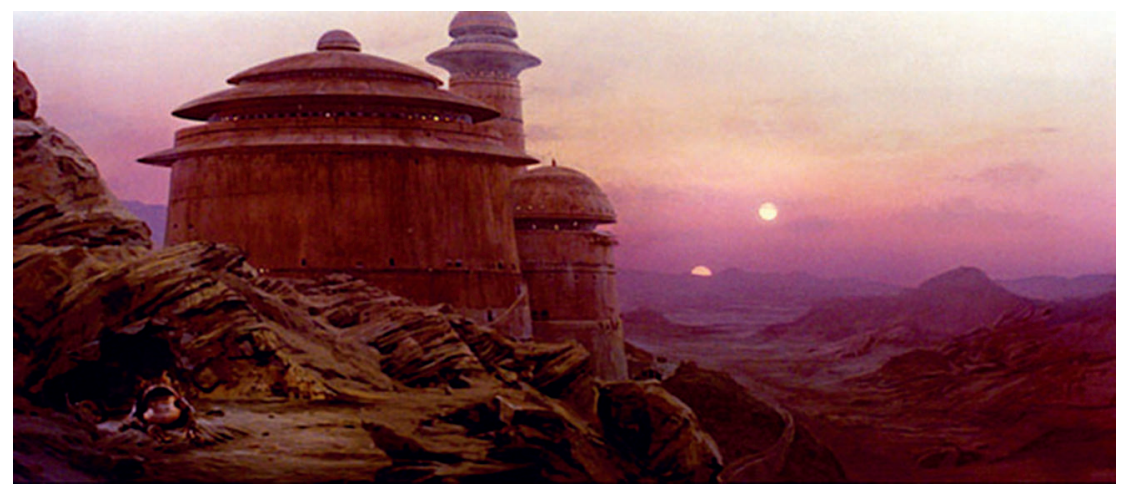

Figura 2.3. Deserto de Tatooin. Imagem do filme Star Wars - A Ameaça Fantasma (1999). 
O surgimento desta técnica vem de encontro com uma das questões filosóficas mais essenciais. A experiência imagética antecede a experiência da linguagem para o ser humano, e nesta reside as sensações, as formas, as cores e as dimensões que moldam a realidade, dos objetos em si mesmos e sua relação com a nossa percepção. A imagem que antes era dada, agora é construída, e impregnada pela espacialidade da produção de cenários e da solidez da representação digital, está ganho o caráter de real, justamente por possuir em seu símile a complexidade que a natureza possui. $\mathrm{O}$ realismo na imagem agora reside na assimilação desta, não pelas semelhanças, mas pelas analogias que esta apresenta.

\section{HISTÓRIA DO DESENVOLVIMENTO DO 3D}

Os estudos do campo da tridimensionalidade gráfica digital começam em meados da década de 1970. A Universidade de Utah mostra os primeiros exemplos de computação gráfica com sombra, com um curta animado 3D chamado $A$ Computer Animated Hand criado pelos futuros fundadores da Pixar, Ed Catmull e Fred Parke. Entretanto, nessa época a imagem tridimensional era algo que somente um programador poderia desenvolver.

Em meados de 1973, George Lucas começa a produzir o primeiro filme da saga Star Wars, entretanto, a indústria de efeitos especiais era praticamente inexistente, portanto, para sua realização foi criado a empresa ILMem 1975. Para a produção deste filme de ficção científica, houve a necessidade da criação de espaços e figuras que escapam a realidade cotidiana, no intuito de dar veracidade a mundos e realidades distópicas, houve a necessidade de uma produção em termos visuais que contemplavam na época, figurino, maquiagem e a produção de maquetes e miniaturas, que eram dispostas em frente a cenários com fundo chroma $k e y^{1}$, e retocadas digitalmente durante a pós-produção.

Aclamado até hoje, a saga Star Wars continha o primeiro uso extensivo da computação tridimensional animada, jamais vista em um filme. Depois do sucesso de bilheteria, foi uma questão de tempo até que as companhias de software criassem programas de efeitos especiais e tridimensionais de mais fácil alcance.

1 Chroma Key é uma técnica utilizada para remover uma tonalidade ou uma gama de tons de uma cor específica. 
Com o declínio dos preços de hardware, houve um "boom" de formação de startups, e assistimos a criação de empresas como a Autodesk, Alias Research, Wavefront e, a Omnibus - que está se tornando a maior empresa de computação gráfica no mundo.

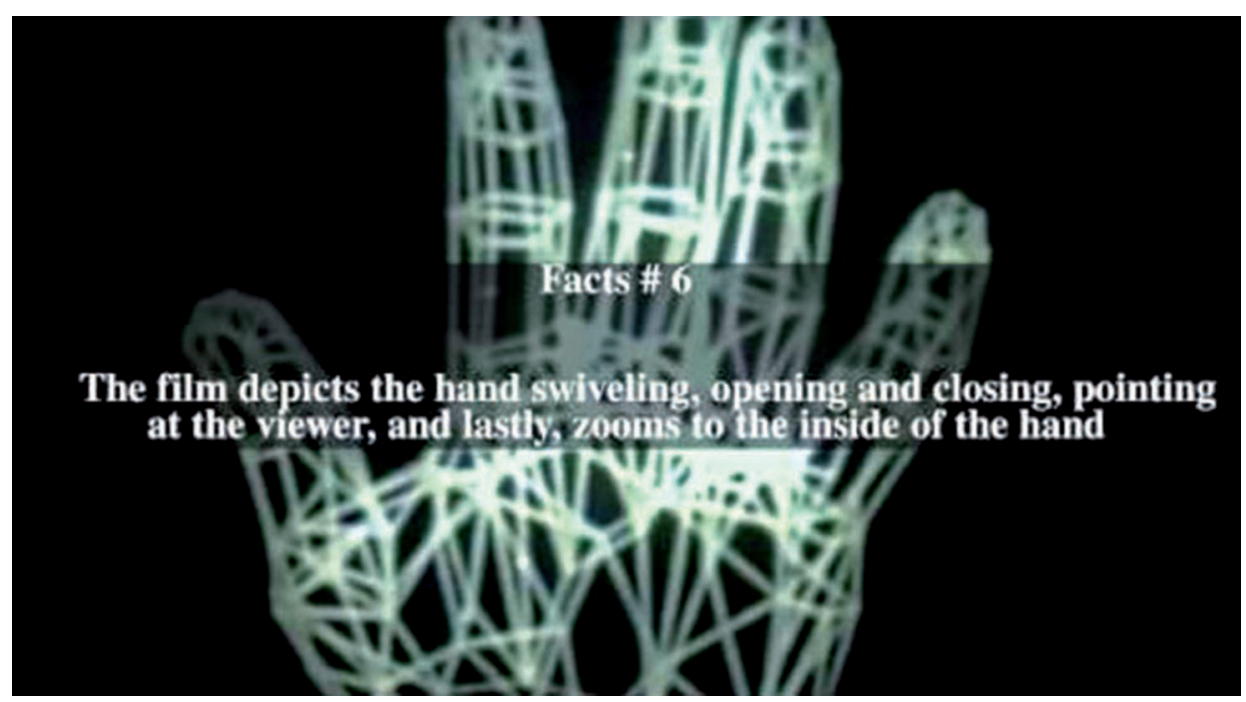

Figura 2.4. Imagem da animação A Computer Animated Hand (1972). ${ }^{2}$

Kim Davidson e Greg Hermanovic trabalhavam para a Omnibus na época e começaram a criar uma versão beta do programa PRISMS (Production of Realistic Image Scene Mathematical Simulation). O que antes era conseguido apenas por meio de programação, agora se torna possível através de uma produção de forma mais visual, pois o programa PRIMS se destacava por conseguir deixar mais automatizado e visível para os artistas. Com o programa PRISMS foram criados os efeitos de filmes gigantescos como Apollo 13, Twister e Titanic.

O tempo de ambos na empresa foi breve, pois após comprar a Digital Productions e Robert Abel \& Associates a companhia entrou em falência. Após o ocorrido, Davidson e Hermanovic criam a empresa Side Effects.

2 Tradução livre do texto da imagem: O filme mostra mão girando, abrindo e fechando, apontando para o observador e por último, zoom para o interior da mão. 


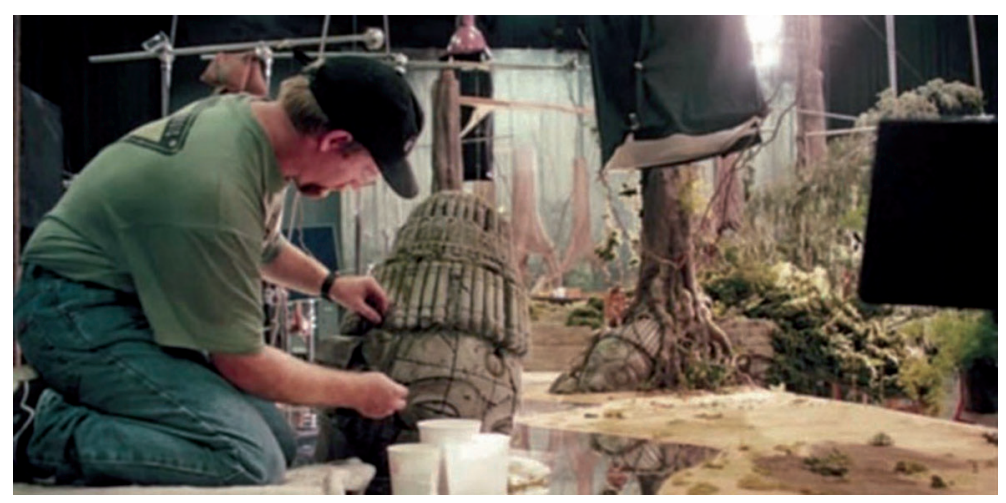

Figura 2.5. Imagem da produção do filme Star Wars - O Império Contra Ataca (1980).

\section{CINEMA}

No fim dos anos 1980 e começo dos anos 1990, a corrida para o desenvolvimento tridimensional estava em alta. Em 1994, os softwares da empresa Alias começam a ser utilizados em filmes como The Abyss, Terminator 2, Jurassic Park entre outros. Em 1983, a empresa Wavefront se uni a empresa Alias, o que determinou de forma categórica, os rumos da indústria de software. O desenvolvedor da empresa Chris Landreth, então, dá início ao que se tornaria o programa Maya. Ao lançar a primeira versão beta do programa, testou-o durante a produção do curta Subconscious Password para provar a capacidade do software. O programa que viria a se tornar o padrão para a indústria do entretenimento, virou o caro chefe da Alias, o que culminou na paralisação da produção de seus outros softwares, com o intuito de alavancar a ferramenta. O Maya hoje é o software padrão das principais empresas de efeitos visuais do mercado de entretenimento como a Weta Digital, a Sony Pictures Imageworks, a ILM e a Tippett Studio.

Em 1995, ocorre o lançamento do primeiro filme longa metragem puramente tridimensional, Toy Story, criado pelos estúdios Pixar, que haviam fechado um acordo com a Disney para a produção de 3 longas metragem de animação. Toy Story foi recorde de bilheteria em seu ano de lançamento, assim como sucesso de crítica, o lucro do longa permitiu que a empresa pudesse investir em tecnologia de software de desenvolvimento, na criação dos programas RenderMan e Marionette. 


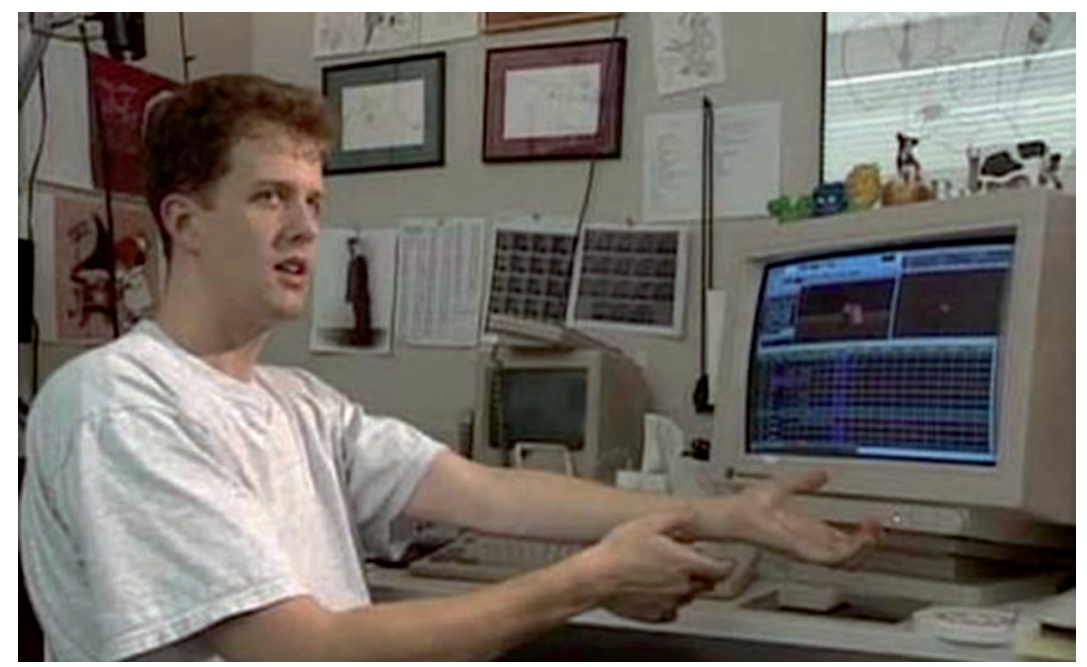

Figura 2.6. Pete Docter, Animador da Pixar, durante o processo de produção do filme Toy Story (1994).

O ano de 1997 é marcado com o filme mais caro da época. Titanic custou duzentos milhões de dólares e precisou de mais de quinhentos efeitos visuais para recriar o desastre. O diretor James Cameron comandou uma equipe que foi até os destroços do navio e fez vastos estudos para que fosse possível recriar, não apenas em estúdio para as filmagens, mas também para a pós-produção. $\mathrm{O}$ diretor de arte, Peter Lamont, trabalhando conjuntamente com a produtora Digital Domain, recriou o naufrágio a partir da utilização de uma maqueta digital sob a qual eram incluídos os efeitos de água e fumaça, também foram necessários o escaneamento dos rostos dos figurantes para a produção de motion capture, assim como a utilização de tela verde para a produção das imagens onde a água inundava as diversas partes do navio. Praticamente $90 \%$ do filme era composto de CGI.

Já o ano de 2001 era marcado pela produção do primeiro personagem humano produzido digitalmente. No filme Final Fantasy, de Hironobu Sakaguchi, a personagem Aki Ross chama a tenção pelo nível de detalhamento atingido pela produção. O filme não chamou a atenção do público ou da crítica, fato que impulsionou a fusão da empresa Square, produtora do filme, com sua rival Enix. 


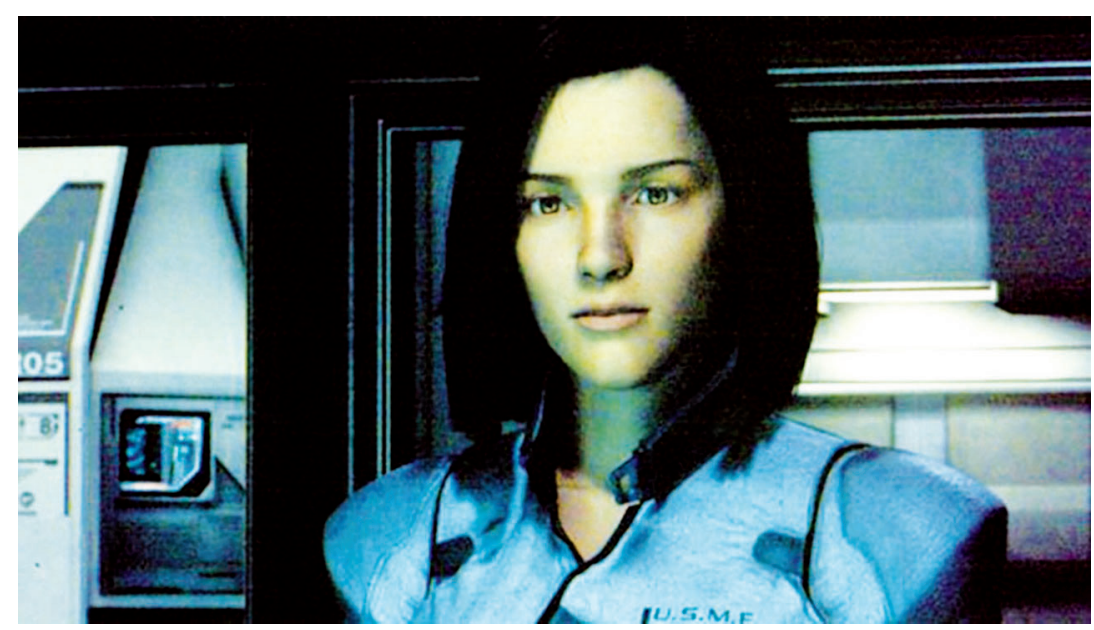

Figura 2.7. Personagem Aki Ross, do longa metragem Final Fantasy (2001).

O ano de 2004 é marcado pelo lançamento do primeiro filme feito inteiramente com motion capture. O filme, O Expresso Polar, de Robert Zemeckis, contava com a atuação de Tom Hanks no papel de 5 personagens diferentes, todas produzidas a partir da captura de imagem e produzidas por computação gráfica. O filme não agradou a crítica, que não estava preparada para o impacto dos personagens totalmente digitalizados, que foram considerados poucos expressivos. O avanço tecnológico permitiu que novas produções como, O Senhor dos Anéis de Peter Jackson, e Avatar de James Cameron, conseguissem efeitos melhores nas expressões de seus personagens e assim, uma melhor recepção de crítica e público.

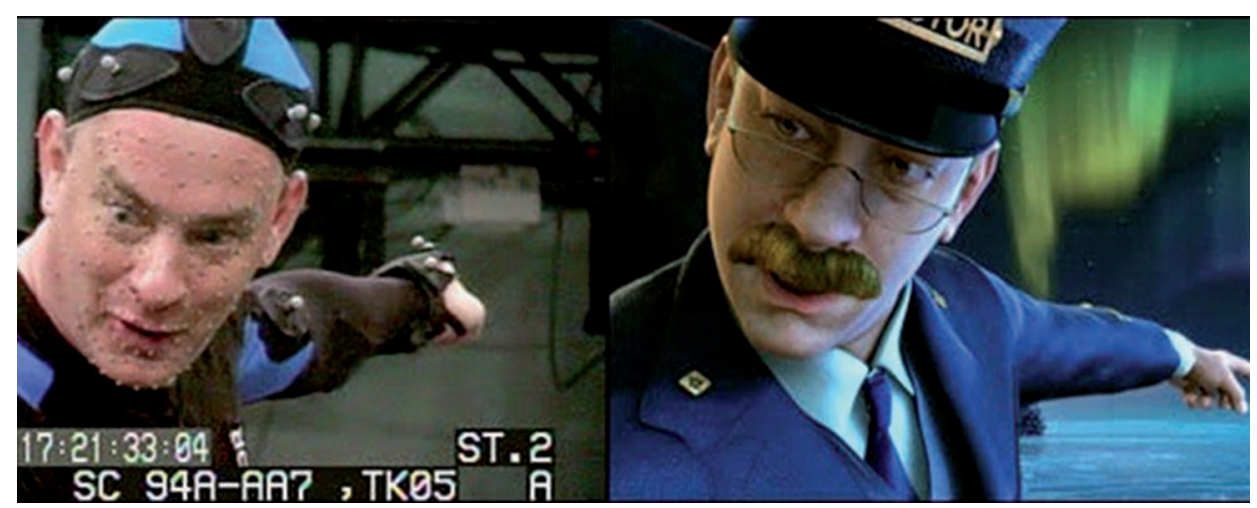

Figura 2.8. O ator Tom Hanks, durante a produção do filme O Expresso Polar (2004). 


\section{TRIDIMENSIONALIDADE GRÁFICA}

Um dos primeiros jogos a utilizar de gráficos interativos (CGI) foi o jogo Tennis ou Pong (1972). Após o lançamento dos primeiros games que utilizavam dessa tecnologia, a área de desenvolvimento de hardware obteve um investimento de grandes proporções. Em 1959, foi criado o TX-2 que detinha diversas interfaces homem-máquina, entre elas, uma caneta especial com a finalidade de auxiliar na produção de desenho diretamente em programas de computador, assim como, o Sketchpad, software criado por Ivan Sutherland, em 1963 no MIT. O programa permitia criar formas simples no computador, algumas bases de interface criadas por esse programa são utilizadas até hoje, como por exemplo, quando um usuário deseja criar um quadrado, não é necessário que ele crie retas perfeitas a mão, ele simplesmente determina a localização e as dimensões do quadrado, o programa então cria automaticamente um quadrado perfeito.

Em 1961, um estudante do MIT, criou o segundo vídeo game, Spacewar. Sucesso de público imediato, este foi visto como uma oportunidade às empresas varejistas em termos de distribuição em massa. Não demorou muito para as grandes empresas se interessarem pelos gráficos em computadores, em particular a $\mathrm{IBM}^{3}$ que rapidamente criou o IBM 2250, o primeiro computador gráfico para uso comercial. Logo em seguida, foi lançado o primeiro console para a televisão, chamado Odyssey, criado pela Sanders Associates, o console era muito simples e barato, ele permitia aos jogadores "moverem" pixels pela tela.

$\mathrm{Na}$ Universidade de Utah ocorreu um dos maiores avanços da computação 3D, utilizando uma técnica de ocultação de parte do objeto, as partes de um objeto que não aparecem na tela não são processadas. Uma técnica excelente para a criação de imagens estáticas, como o famoso "bule de Utah”, objeto tridimensional que se torna um ícone do desenvolvimento de CGI. Além disso, é criado em 1978 o conceito de Bump Mapping (um mapa de escala tonal branca e preta) que

3 Em 1896, Herman Hollerith, cria a Tabulating Machine Company, que introduz a novidade de trocar os papeis perfurados por cartões (máquinas elétricas capazes de somas e contagens de dados, representados por papel perfurado). Estes cartões se tornariam o elemento base das máquinas IBM para processar dados. Em 1911, duas outras empresas são fundadas, a Time Recorde Co. e a Computing Cale Co. e assim, se unem a empresa de Hollerith formando a Computing Tabulating Recording Co. Em 1924 a CTR muda de nome para Internacional Business Machines, a atual IBM. 
permite a criação de superfícies desiguais, promovendo um aspecto com mais relevo de detalhes no objeto.

Em 1980, se inicia a comercialização de CGI, e com isso, um crescimento exponencial da influência dos Games na cultura pop mundial. Começam as revoluções gráficas com os jogos da Nintendo, com o console Famicom (Ou como ficou conhecido mais tarde como NES), onde os jogos passam a ser em 8bits e em cores simples, lançando franquias famosas até hoje como, Mario e Donkey Kong.

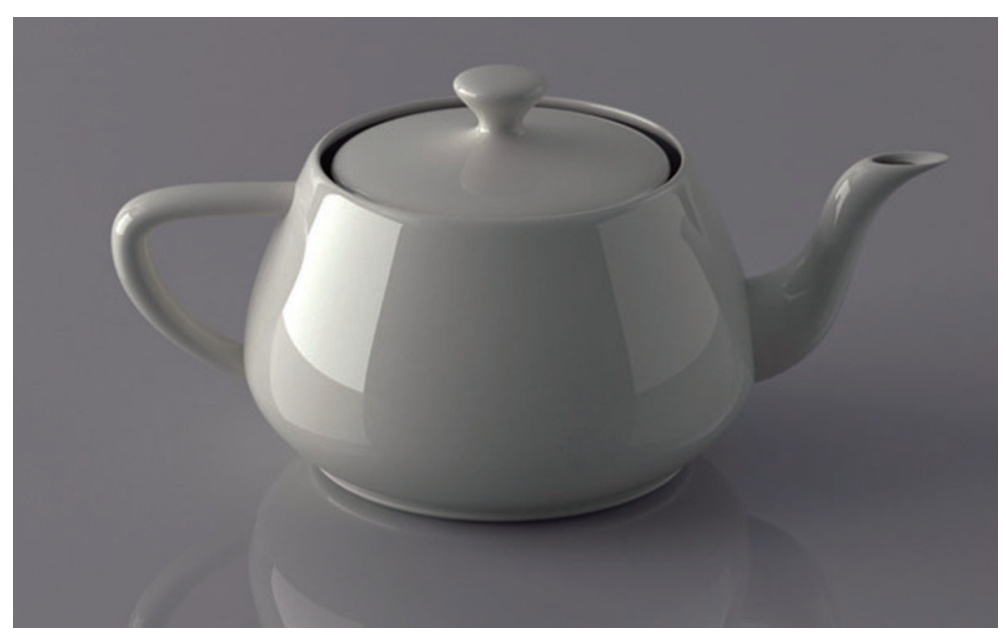

Figura 2.9. Bule de Utah. Utilizado até hoje para referência de material e shaders.

Para concorrer com a crescente Nintendo, a SEGA lança o MegaDrive, primeiro console que utilizava 16bits. Dando continuidade a essa corrida tecnológica, a Nintendo lança o Super NES, criando jogos de qualidade gráfica nunca vistos anteriormente.

Não demorou muito para a entrada de outras empresas concorrentes como a Sony, já lançando jogos de grande aspecto visual. Sem grande repercussão, a SEGA tenta lançar o Saturn, console de 32bits.

Infelizmente para a empresa, logo depois do lançamento do console, a Nintendo anuncia o seu mais novo console, o Nintendo 64, que obviamente continha gráficos de 64bits. A Sony lança o Playstation para concorrer com os jogos da Nintendo e a empresa SEGA sai da batalha dos consoles se tornando uma third party (empresa que produz jogos para outras plataformas de outras empresas). 
A batalha entre Sony e Nintendo aumenta o desenvolvimento do hardware voltado aos consoles. A arquitetura dos consoles vai ficando cada vez mais parecida com a dos computadores. $\mathrm{Na}$ busca por modelos mais realistas, para jogos mais realistas, é necessário perceber a importância de todos os aspectos visuais do jogo, pois, até mesmo uma folha de uma árvore colocada com um material (shader) diferente faz essa realidade se quebrar.

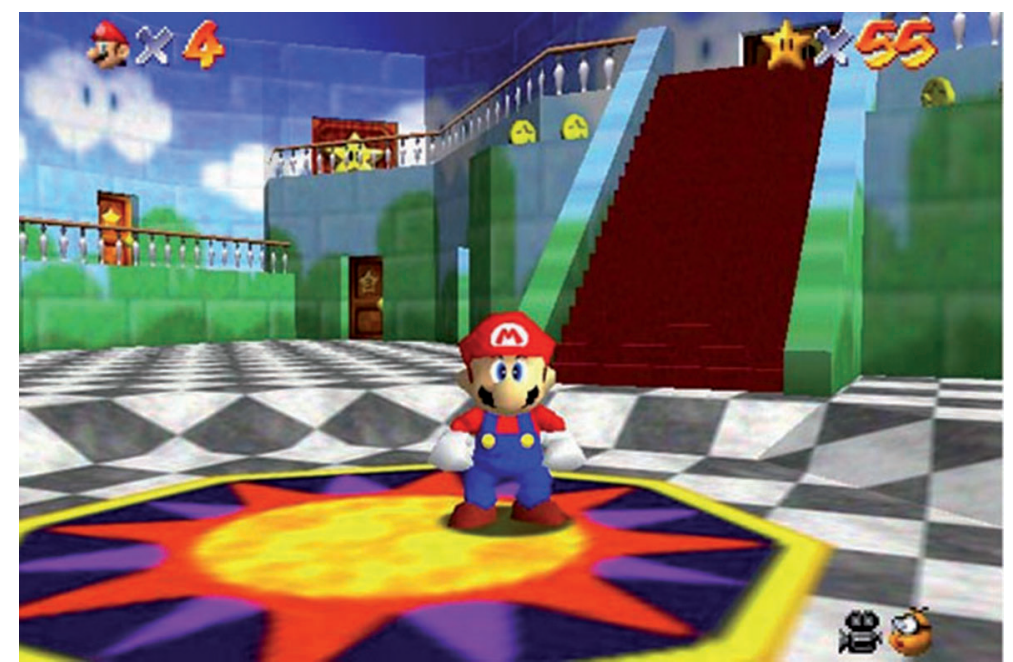

Figura 2.10. Print Screen de tela do jogo Super Mario 64 para console Nintendo 64 (1996).

$\mathrm{Na}$ busca por esse realismo, pesquisadores e desenvolvedores de jogos tentam criar novas formas de recriar a sensação visual de cada objeto utilizando-se das mais diversas técnicas. Os modelos tridimensionais são compostos por planos vetoriais comumente chamados de mesh ou malha. Cada plano consiste de no mínimo, três bordas e três pontos, esses modelos representam um corpo físico em um espaço tridimensional, conectado por diversas linhas e triângulos.

O primeiro console a utilizar gráficos 3D foi o Super Nintendo em 1993, o hardware permitia criar polígonos simples e formas coloridas. Com o jogo Star Fox, fora criado o primeiro jogo para console com gráficos realmente tridimensionais. Um ano depois, a Sony lança o PlayStation One, o hardware já possibilitava o uso de texturas, imagens que complementavam os polígonos e até a reflexão de luz, tornando os modelos mais detalhados. Com jogos como Bandicoot, Resident Evil e Silent Hill, o qual os personagens eram em 3D, mas o cenário era 
em imagens estáticas, e era possível criar a ilusão de um mundo tridimensional completo.

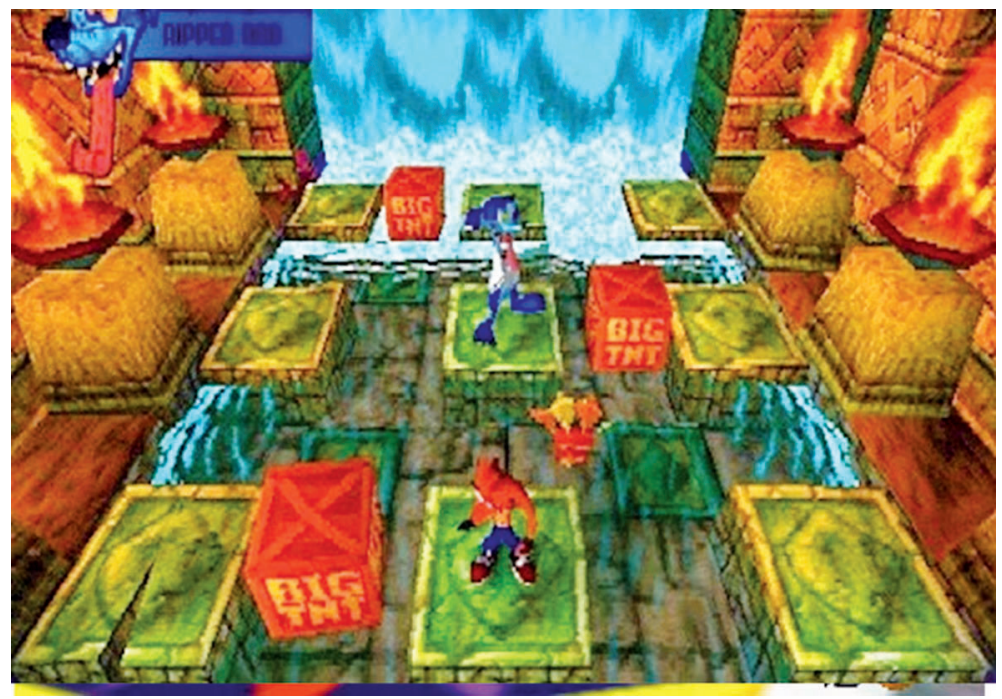

Figura 2.11. Print Screen de tela do jogo Bandicoot para PlayStation One (1995).

Em 1996, a Nintendo lança o Nintendo 64, o console foi projetado para suportar jogos inteiramente tridimensionais, graças ao uso de cartuchos, era possível um carregamento mais rápido das cenas, melhores texturas e maior número de polígonos. Com isso, a Nintendo pode trazer diversos jogos inteiramente tridimensionais como Super Mario 64, The Legend of Zelda: Ocarina of Time e Donkey Kong 64.

No ano de 1998, a Sega lança o Dreamcast, cuja maior qualidade era fornecer um Anti-Alising considerável, ou seja, conseguia reduzir os serrilhados dos modelos tridimensionais tornando-os mais lisos.

Em 2000, a Sony lança o PlayStation 2, com gráficos muito parecidos com o do Dreamcast, conquanto em 2001, começaram a ser lançados jogos com muito mais polígonos e, portanto, mais qualidade gráfica como God of War, Shadow of the Colossus entre outros. A Nintendo lança em 2001 o Game Cube, um console poderoso na parte de gráficos tridimensionais e o primeiro console a usar Pixel Shaders e efeitos de pós-processamento.

No final do ano de 2001, a Microsoft lança o seu próprio console, o $X b o x$, que tinha como vantagem a utilização do Direct $X$, uma arquitetura de 
programação para processamento gráfico, até então somente utilizado nos computadores à otimização da placa gráfica para o sistema operacional Windows. Essa semelhança facilitou o trabalho dos desenvolvedores que já desenvolviam jogos para computador, pois não tinham de aprender uma programação diferente especificamente para esta plataforma, portanto, era possível chegar a uma qualidade muito próxima da obtida nos computadores pessoais sem grande esforço.

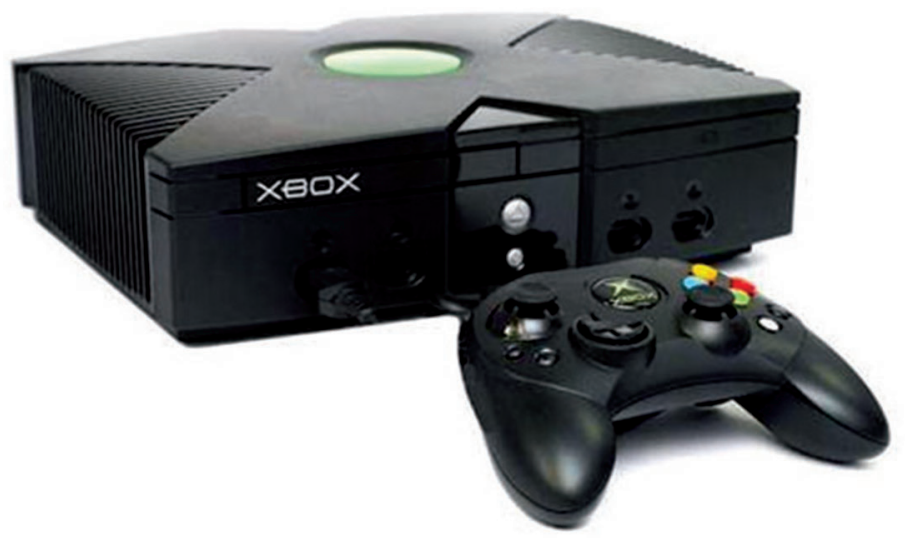

Figura 2.12. Console Xbox, Microsoft (2001).

\section{ASPECTOS TÉCNICOS}

Um dos campos responsáveis pelo atual desenvolvimento tecnológico em grandes áreas artísticas como a animação e os games é a Computação Gráfica (CG). Esta área, comporta atividades tais como: modelagem, criação, manipulação de imagens, renderização, conversão de cenas em imagens, cálculo para processamento de imagens, iluminação, criação de materiais, animação entre outros. Entre suas inúmeras aplicações, podemos citar sua contínua utilização em projetos de arquitetura, pinturas digitais, design amigável ao usuário aplicado aos softwares interativos, processamento de imagem, simulações, etc. A computação gráfica tem passado por uma metamorfose dinâmica e acelerada, que começa com computadores cuja linguagem é textual e as imagens são pixelizadas, indo de encontro com a produção de imagens de alta qualidade, fotorrealistas ao 3D. 
Em 1950, quando surge, seu visual é primordialmente tipográfico e catódico, e as imagens eram produzidas através de uma justaposição de caracteres claros e escuros. Já em 1960, começam à ser produzidas as primeiras interfaces gráficas interativas, o público neste momento enfrenta o problema de custo de produção e acessibilidade destas máquinas. No início dos anos 1970, a produção começar a usar telas bitmap ${ }^{4}$, embora a capacidade gráfica seja ainda, muito simples. Em meados da década de 1980, a interface gráfica é feita a partir de imagens bitmap e pixel ${ }^{5}$.

Os custos dos computadores diminuem drasticamente. Na década de 1990, ocorre a introdução do $\mathrm{VGA}^{6}$ e $\mathrm{SVGA}^{7}$, e agora o computador pessoal pode facilmente exibir imagens e filmes fotorrealistas. Renderizações de imagem 3D tornam-se os principais avanços deste período e o estimulo a criação de aplicativos gráficos com prioridade na produção cinematográfica ganham força. A partir dos anos 2010, entramos na fase de criação e implementação de dispositivos de realidade virtual. Há a necessidade de um maior desenvolvimento de instrumentos imersivos ligados a computação gráfica que permitam uma maior experiência sensorial por parte dos usuários, ainda que o carro forte dos avanços tecnológicos esteja na produção de imagens de alta qualidade.

Para além do desenvolvimento de técnicas de computação gráfica com vista numa melhor experiência interativa nos novos meios de entretenimento, vemos também novas aplicações dessa tecnologia em outras áreas, como a médica e a laboratorial, a fim de auxiliar pesquisadores e cientistas no desenvolvimento de seus experimentos.

A computação gráfica nasce da necessidade da conversão de dados em imagens que atendam a necessidade do usuário. Quando as necessidades dos usuários e das instituições de pesquisas se unem as inovações tecnológicas, temos um maior desenvolvimento de novas representações geométricas tridimensionais, na

4 Bitmap:Imagens que contêm a descrição de cada pixel através de um conjunto de bits, em oposição aos gráficos vetoriais.

5 Pixel:É o menor ponto que forma uma imagem digital.

6 VGA:Video Graphics Array é um padrão de transmissão de dados gráficos de computadores introduzido em 1987 pela IBM.

7 SVGA: Super Video Graphics Array, é uma denominação genérica que cobre uma ampla gama de padrões de placas de vídeo para computadores. 
criação de novas estratégias de visualização e colaboração em ambientes virtuais interativos, na projeção de sistemas de softwares que permitem uma ampla gama de formatos de exibição e em multiplataformas.

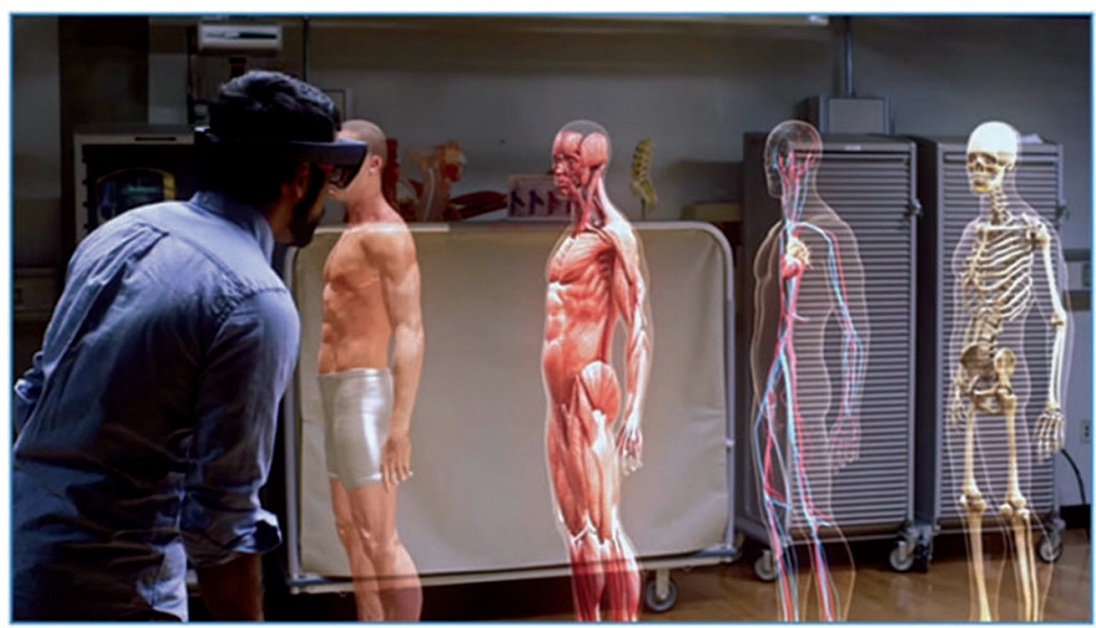

Figura 2.13. Um dos usos da realidade virtual para a área médica.

A necessidade de uma melhor representação de objetos tridimensionais está no cerne da computação gráfica desde o início do seu desenvolvimento. Os objetos aos quais estamos expostos continuamente em nosso cotidiano tem uma forma particular e modificam o espaço em que estão inseridos, possuem superfícies externas muitas vezes não transparentes ou translúcidas, variam em forma, textura e cor. Estes aspectos têm sido trabalhados nesta área de forma progressiva através de algoritmos, que são parte da ferramenta utilizada na programação e desenvolvimento de software. A maior parte dos algoritmos são produzidos de forma a gerar objetos de maneira mais eficaz e rápida, a partir de dados como a posição e a forma, muitas vezes, restringindo sua aplicabilidade pela falta de informações.

Como a quantidade de dados necessários para determinar a posição de cada ponto da superfície de um objeto que é muito grande, temos que fazer algumas suposições simplificadoras. A escolha destas simplificações decidirá a forma da estrutura de dados usada para armazenar estes objetos e também vai limitar a escolha do algoritmo. É importante perceber que não há nenhum algoritmo único, que funciona igualmente bem em todos os processos e níveis de desenvolvimento. 
A importância de ressaltar tais aspectos da recente história do desenvolvimento das imagens digitais $\left(\mathrm{CGI}^{8}\right)$ é necessária à medida que nossa investigação aponta uma nova utilização destas ferramentas em linguagens antes ignoradas por seus predecessores. Hoje, um dos principais objetivos dos produtores e diretores de games e animações de efeitos especiais é a produção de imagens com altos níveis de realismo. A computação gráfica volumétrica assume atualmente um papel chave na produção de imagens com capacidade de imersão total, aspecto fundamental na construção de mundos virtuais.

$\mathrm{Na}$ busca por esse realismo, pesquisadores e desenvolvedores de jogos tentam criar novas formas de recriar a sensação visual de cada objeto utilizando-se das mais diversas técnicas. Os modelos tridimensionais são compostos por planos vetoriais comumente chamados de mesh ou malha. Cada plano consiste de no mínimo três bordas e três pontos, esses modelos representam um corpo físico em um espaço tridimensional, conectado por diversas linhas e triângulos.

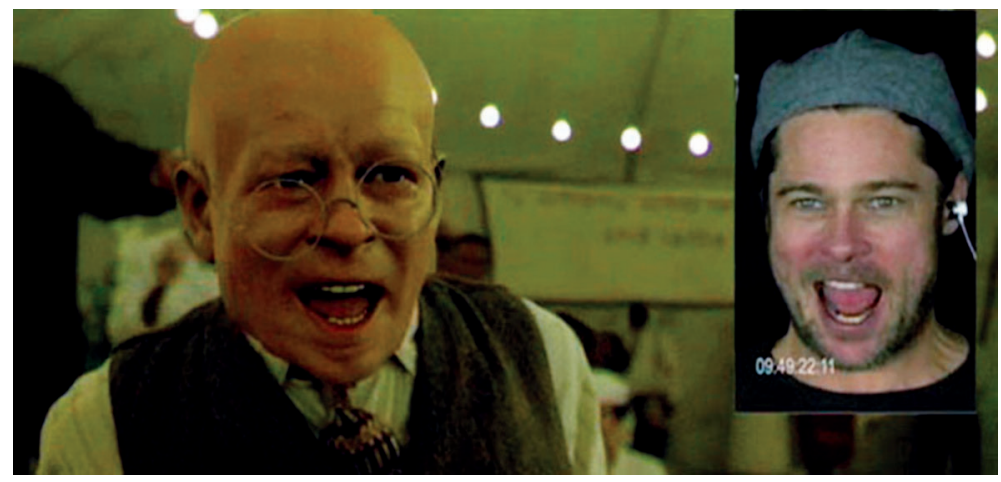

Figura 2.14. O ator Brad Pitt durante a produção do filme O Curioso Caso de Benjamin Button (2008).

Quase todo modelo tridimensional pode ser dividido em duas categorias, modelo orgânico e inorgânico, o primeiro representa objetos que tem vida ou que sejam animados causando uma distorção da sua forma original; árvores, pessoas e animais. Objetos inorgânicos são todos os objetos que mantém sua estrutura base, como uma pedra ou um copo.

Além disso, estas duas categorias podem ser divididas em duas subcategorias cada uma. Uma delas é o objeto sólido, ou seja, deve-se definir o volume que ele

8 CGI:imagens geradas via computador. 
representa. São objetos mais realistas, mas mais difíceis de criar. A outra forma de objeto tridimensional é a de aparência de superfície. Estes são muito mais leves de trabalhar pois não exigem um tratamento volumétrico. Por esse motivo, esses modelos são usados em jogos e filmes. Para a modelagem existem três modos de produção; modelagem poligonal, que consiste em estender e controlar cada ponto que compõe um modelo;

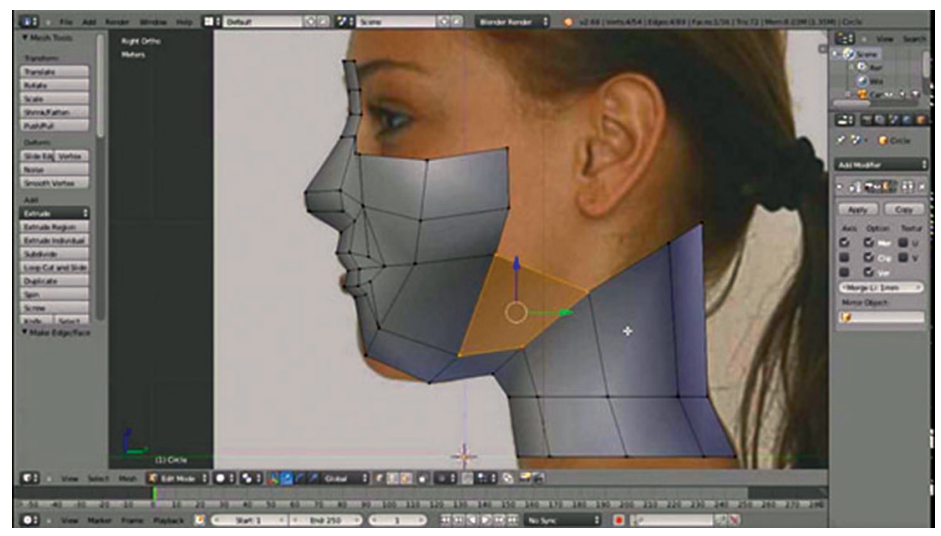

Figura 2.15. Modelagem ponto a ponto realizado no programa Blender.

A modelagem em curvas ou NURBS

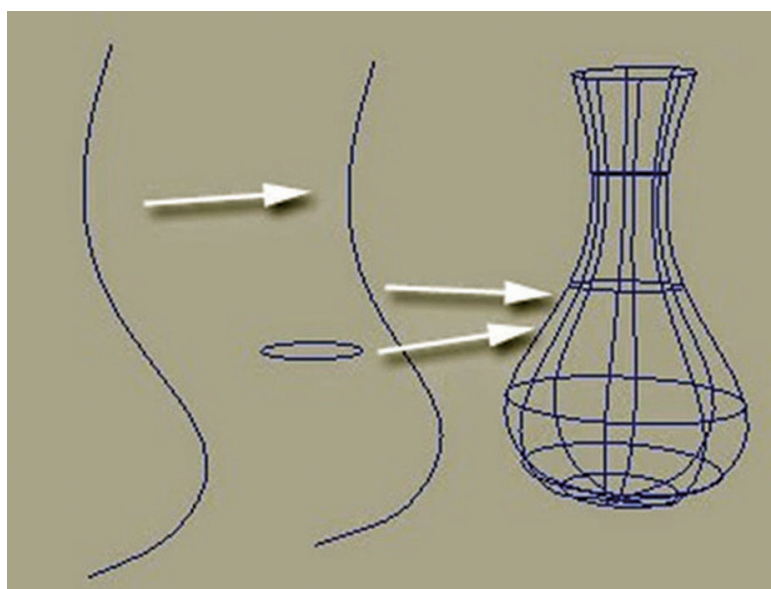

Figura 2.16. Modelagem em curvas.

9 NURBS: Nonuniform rational B-spline (modelo matemático para gerar uma curva a partir de pontos e retas). 
Também temos a escultura digital, que consiste na reprodução em argila virtual, onde o modelador dispõe de ferramentas parecidas com as que ele pode encontrar na realidade para esculpir seu modelo sem se preocupar com cada face da malha tridimensional.

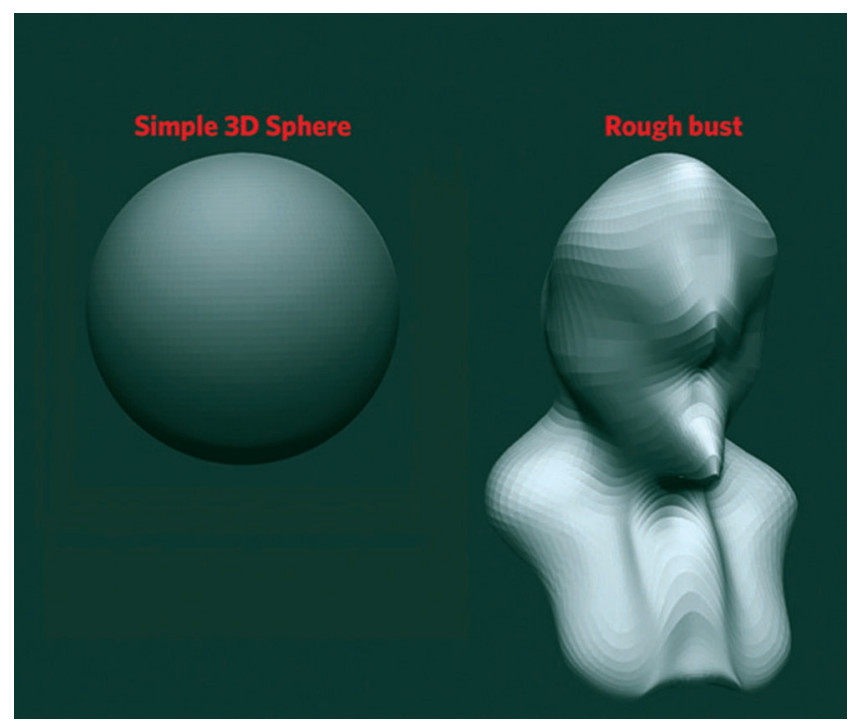

Figura 2.17. Modelagem como escultura digital.

Além da modelagem, quando falamos em tentar alcançar uma imagem realista temos que referenciar aos tipos de mapas de representação que devem estar presentes no próprio modelo como:

O mapa de cor.

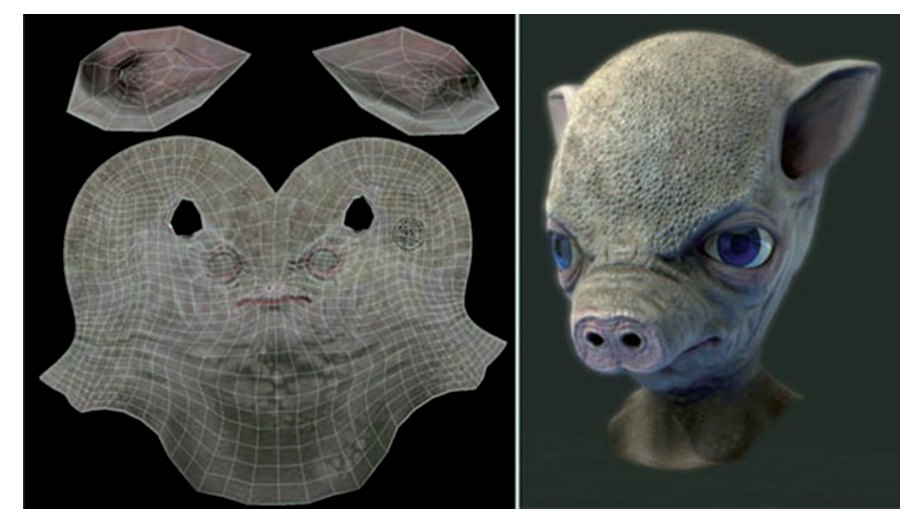

Figura 2.18. Modelo referencial para mapa de cor. 
O bump map (que confere a sensação de superfície desigual).

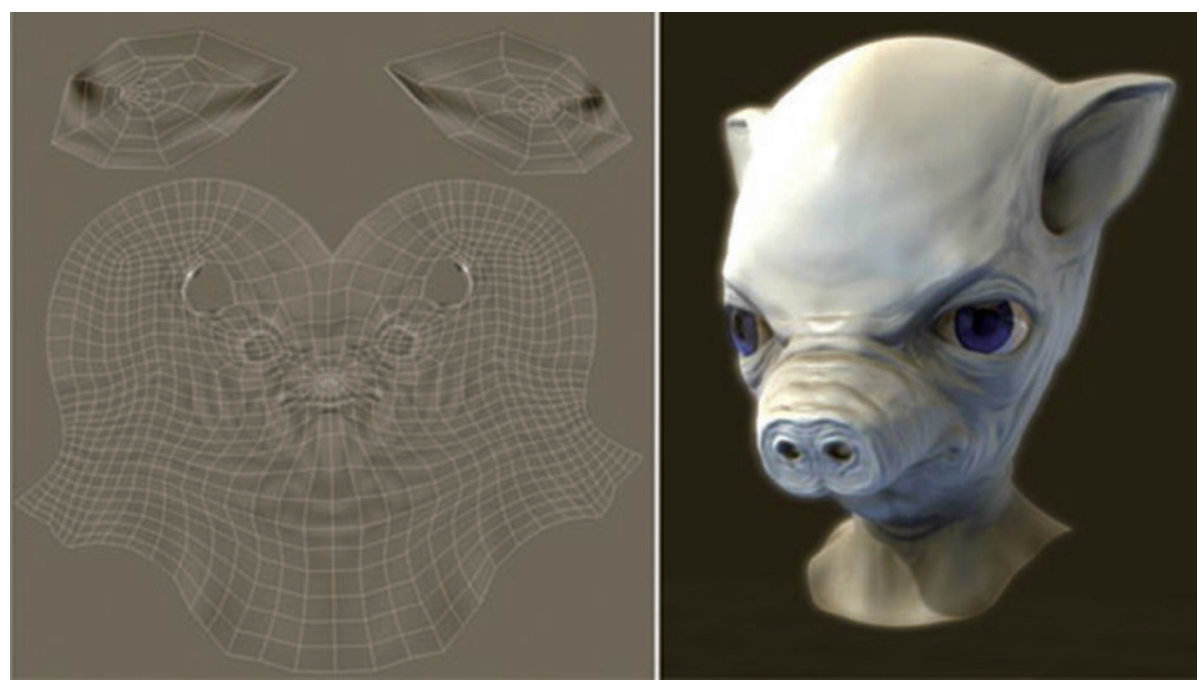

Figura 2.19. Modelo referencial para bump map.

O specular map (Define o quanto o objeto reflete o brilho da luz).
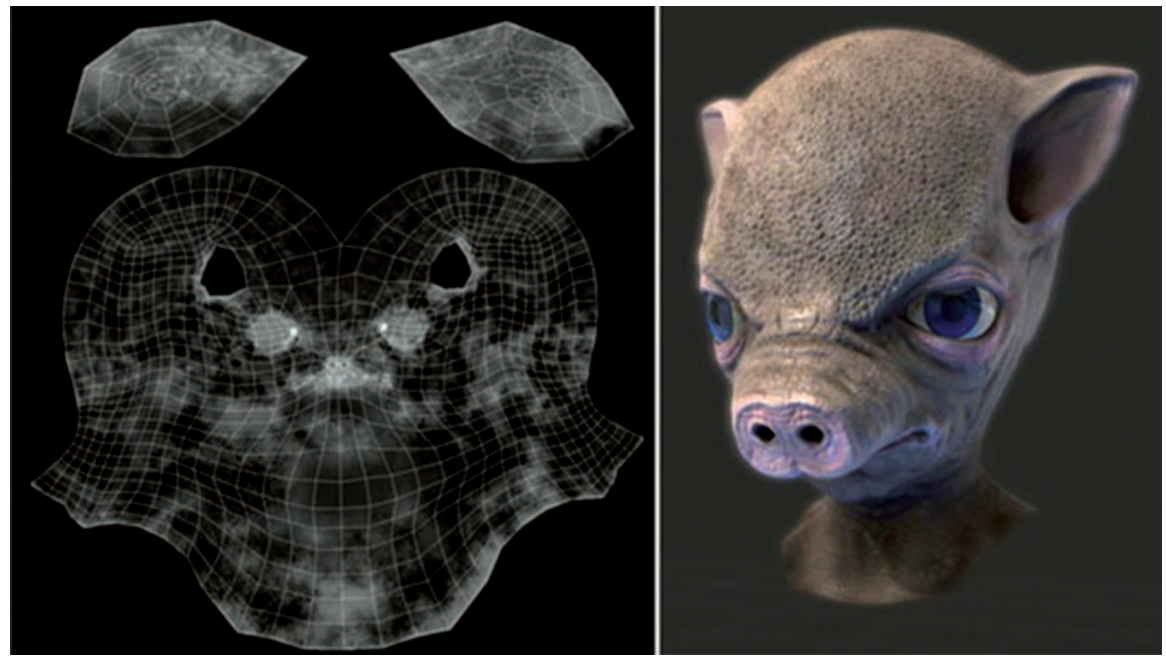

Figura 2.20. Modelo referencial para specular map.

O displacement map (Gera polígonos através de um cálculo da representação da imagem utilizada como mapa). 


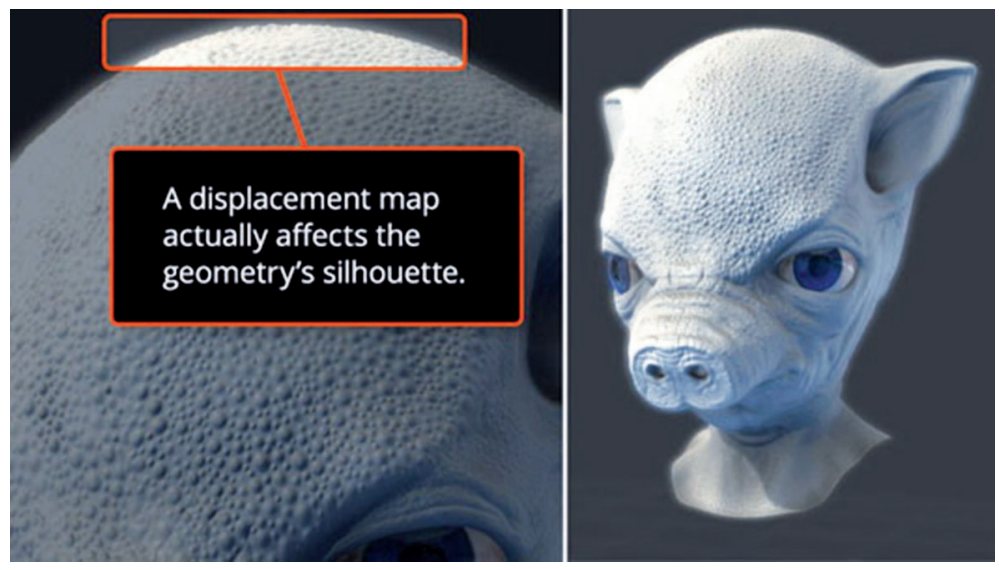

Figura 2.21. Modelo referencial para displacement map.

O mapa de transparência.

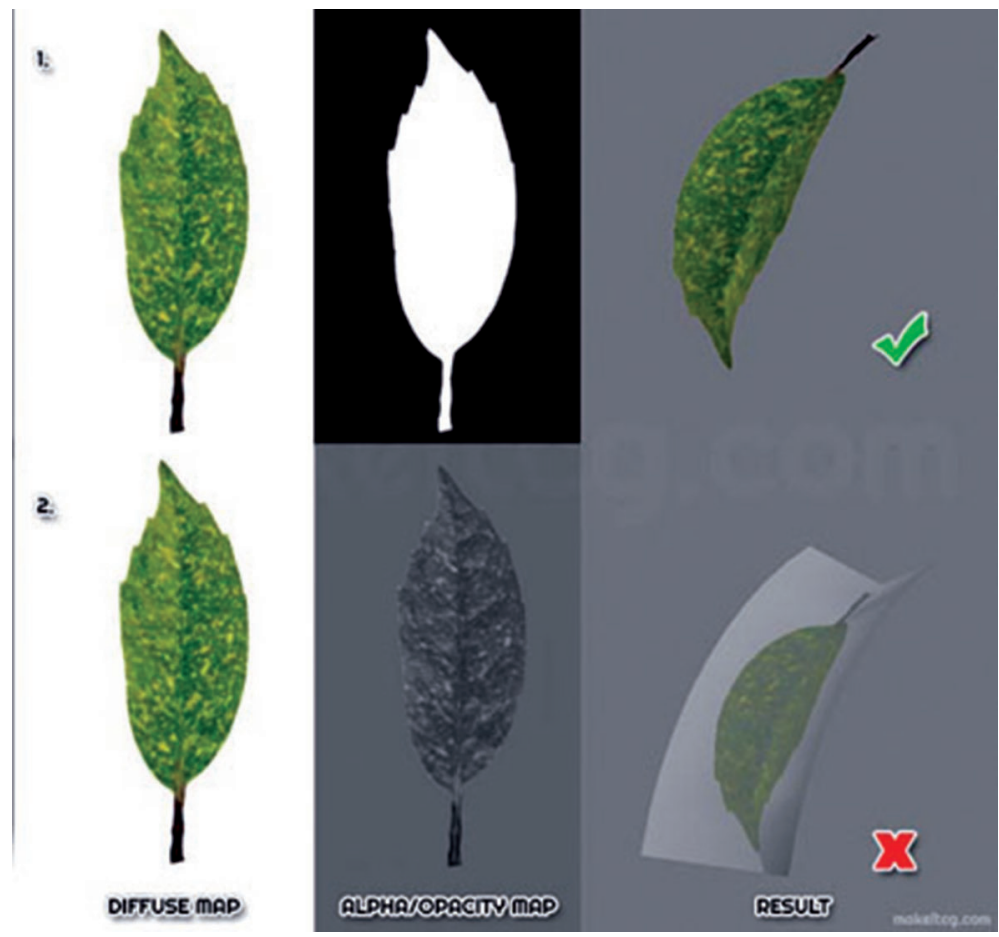

Figura 2.22. Modelo referencial para mapa de transparência. 
O mapa de reflexão;
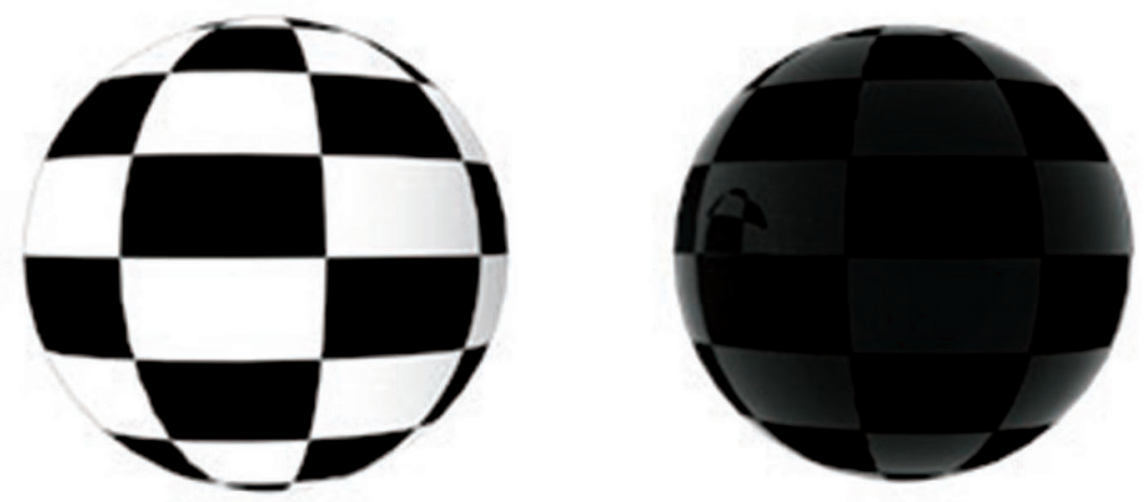

Figura 2.23. Modelo referencial para mapa de reflexão.

E o normal map (Cálculo matemático de entrâncias para efeito da luz e sombra).
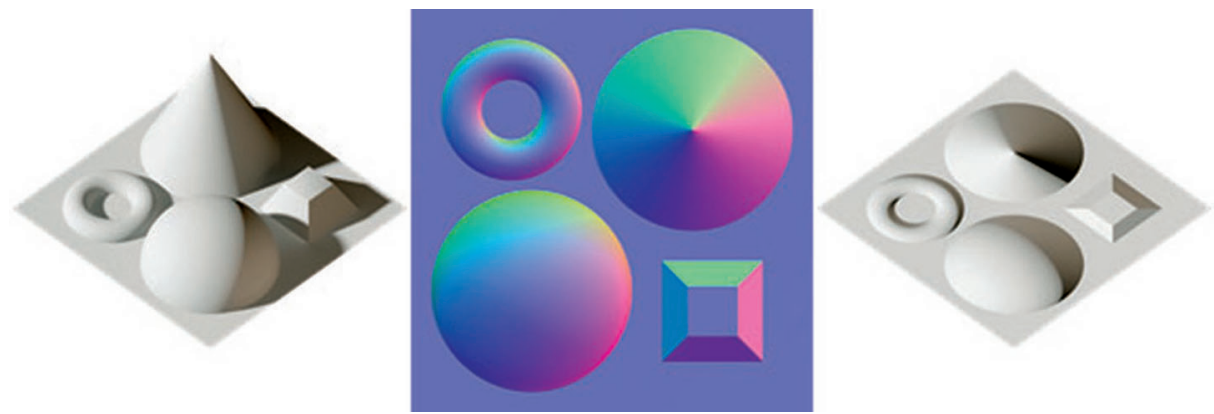

Figura 2.24. Modelo referencial para normal map.

Entretanto surge a dúvida, de que forma esses mapas podem ser implementados nos modelos tridimensionais. Para isso é utilizado o UV map (Mapa de coordenadas que utilizam os eixos X e Y, ou horizontal e vertical) para fazer uma representação do modelo tridimensional em duas dimensões.

Ao ser criado o mapa de coordenadas, o modelador utiliza a figura formada como base e com a utilização de um programa de edição gráfica ele pode alterar a imagem para se acomodar ao padrão estabelecido pela UV. Além de todos esses mapas, também é imprescindível trabalhar com os shaders, ou materiais, já que é este o que vai definir onde todos os mapas deverão ser usados. 


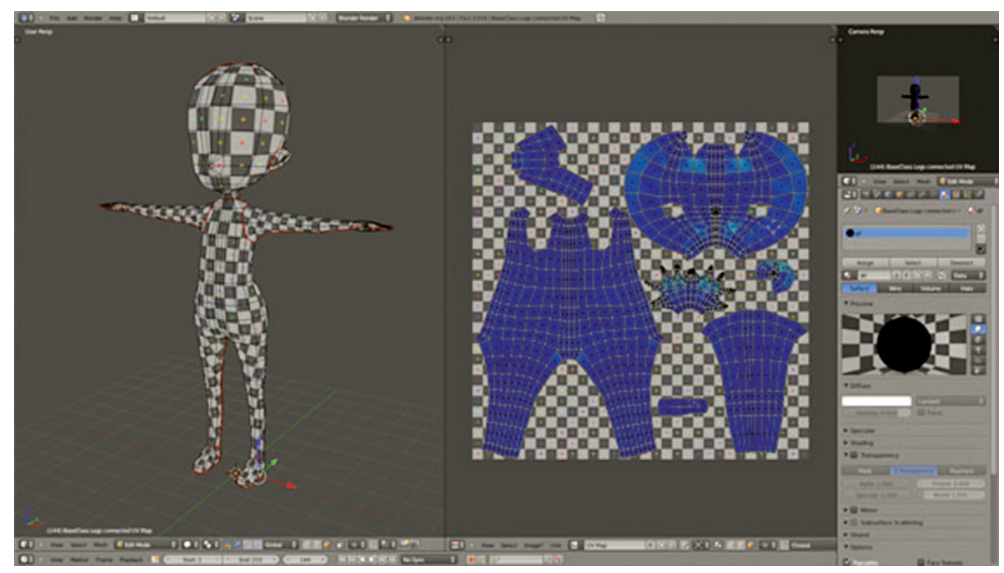

Figura 2.25. Mapa UV do modelo tridimensional para uma representação bidimensional.

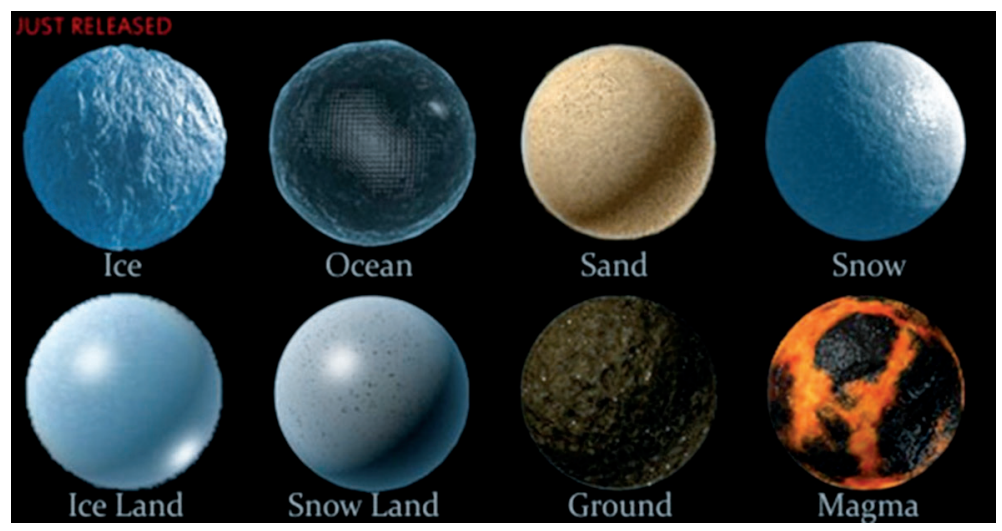

Figura 2.26. Tipos de shaders/materiais.

\section{D E IMERSÃO}

Desde o momento de seu nascimento, o indivíduo é inserido em um mundo de formas, cores, sensações e estímulos. Este mundo no qual o indivíduo é inserido modifica-o ao longo dos anos, por intermédio de suas experiências, assim como este mundo é modificado por ele a partir de suas necessidades e desejos. Detentor de subjetividade, o indivíduo passa a agregar valor ao espaço que ele habita, e ao interpretá-lo, passa a agregar significado e significância ao que está a sua volta. A medida que o indivíduo interpreta o espaço em que está inserido, este também passa a idealizá-lo ou ainda, a fantasiar com outras possibilidades. 
É por intermédio da arte, que este encontra linguagens capazes de dar vazão a este anseio por outros mundos possíveis.

Toda a tecnologia que o ser humano utiliza partiu do mundo das ideias, diante da necessidade de resolução dos problemas do dia-a-dia, o ser humano passa a criar ferramentas capazes de suprir suas necessidades, a arte surge como uma dessas vias, de externar ideias, imagens, conceitos. A representação digital não foge à regra, tudo o que o ser humano cria é na verdade uma adaptação de algo que este já tenha visto ou experienciado, tudo é transformação. O mundo imaginário que esta nas cabeças de crianças e adultos, com dragões, cavaleiros, magia, civilizações utópicas e diatópicas existem como uma interpretação de situações existentes, portanto elas são reais dentro da imaginação de quem as pensa. A evolução tecnológica permite, ou, sempre vai em busca dessas ideias, e tenta torná-las tangíveis, possíveis de visualizar ou sentir.

Dentro da história da arte, as linguagens que precedem o 3D são limitadas em termos estéticos, pois as mesmas, como a literatura e a poesia, necessitam um maior investimento por parte do leitor para a criação de espaços. O mesmo necessita utilizar da imaginação para criar os cenários, mesmo que o texto esteja impregnado de descrições. No entanto com as artes pictóricas, o cenário é diferente. A arte não é fixa, ela é moldada pela experiência do indivíduo que a observa. Os quadros necessitam de experiência para serem interpretados, pois cada indivíduo possui sua própria forma de perceber o mundo, o que se reflete no momento da experiência de contato com a arte.

Diante disto, o 3D de certa forma, vai de encontro com as necessidades dos artistas na medida em que esta técnica possui uma maior gama de detalhamento. $\mathrm{O}$ artista agora pode dar existência aos espaços e personagens que habitam sua mente, e agora a experiência do expectador ganha nova forma, pois o mesmo se encontra diante de novos mundos com possibilidades outras, escapando a sua realidade.

No cinema de animação, e nos games, o 3D é utilizado como artifício na medida em que a nossa percepção da realidade é tridimensional, condicionando o cérebro a uma melhor aceitação e interpretação da realidade apresentada, tornando o processo de imersão mais agradável. Através da existência dos modelos e de mundos tridimensionais, os mundos de fantasia e ficção científica, tão aclamados pelos leitores agora ganham forma crível e representativa no mundo "real" do jogador e expectador. 
O cinema funciona como uma janela do mundo, que mostra uma perspectiva única. Só é possível ver o que está dentro do plano enquadrado, de acordo com os desejos do diretor. É no plano, onde o expectador recebe as informações, mas precisa emular o que está fora do plano. Os jogos tridimensionais permitem uma ampla visualização a partir do momento em que o movimento da câmera pode ser rotacionado fornecendo a ele uma experiência completa do que está inserido no mundo apresentado.

Como visto anteriormente, de acordo com Janet Murray, o ambiente digital pode ser descrito como um sistema tríade. Com a possibilidade de haver uma imersão maior devido a utilização do 3D como fonte visual, consequentemente, o jogador tem uma sensação de agência maior, pois sente que suas ações tem um efeito maior durante a ação do jogar. Ao navegar em um ambiente tridimensional, o jogador tem percursos ilimitados, pode percorrer cenários que não tenham ligação direta com a trama central, ou mesmo, como parte da narrativa do jogo, se apresentando como um desafio a ser enfrentado. Além disso, à possibilidade de um mundo aberto e gigantesco, a pessoa pode desenvolver a sua própria história, não necessariamente se prendendo ao enredo do jogo. Caso, o jogo detenha um mundo aberto, como no caso de jogos exploratórios, o usuário pode decidir nunca seguir o jogo adiante e simplesmente vagar por esse planeta misterioso e novo.

A questão da interação e do protagonismo em relação a obra de arte já foi tema de obras celebres como Fabrenheit 451, obra de Ray Bradbury adaptada para o cinema por François Truffaut, e que mostra Julie Christie interagindo com a TV de sua sala como se esta fosse uma das personagens da novela. Na obra Tron, do cineasta Steven Lisberger, o personagem Flynn é escaneado e transportado para o mundo virtual onde sua sobrevivência depende de suas ações em relação a esse mundo outro. No clássico Alice no país das maravilhas e Alice através do espelho, Lewis Carroll já ilustra esse desejo do ser humano de um portal que o permite conhecer um novo mundo capaz de deixá-lo embevecido. O que percebemos no decorrer da história da arte, é que esse desejo vem de encontro com a utilização da linguagem tridimensional na feitura de jogos, na medida em que a narrativa se distância da produzida pelo cinema, por alterar as formas de interação e simbiose entre expectador e personagem;

"A ideia dominante, e até estereotipada, faz do cinema a imagem fiel, sem outros truques além dos convencionais (em primeiro lugar, a montagem), de uma realidade 
que deveria ser captada por si mesma através de uma imagem transparente como a de um espelho perfeito. É não dar a devida importância a toda uma parcela de arte cinematográfica, aquela que mais se ocupa das imagens do que de sua fidelidade das próprias imagens, tal como o cinema, após as outras artes, as inventa e as faz viver. Por mais poderosa que seja a força da impressão da realidade, ao assistir a uma sessão de cinema, à princípio, só me submeto a um fluxo perceptivo, o das manchas luminosas veiculadas pela luz do projetor e materializadas na tela." (AUMONT, 2004, p. 54)

Com o advento dos games, saímos da posição de expectador. Passamos a desempenhar o papel de Alice, que desvenda um mundo de maravilhas através do espelho, muitas vezes, sem uma direção especifica, mas pelo puro prazer da exploração.

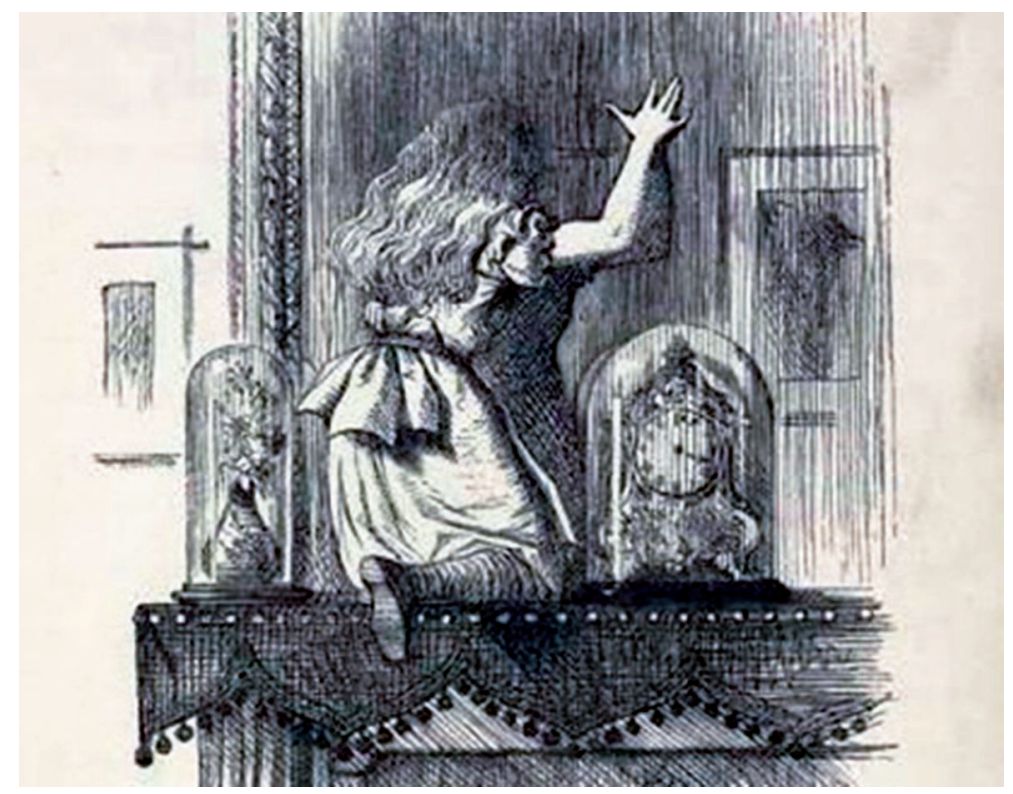

Figura 2.27. Ilustração do livro Alice através do Espelho, de Sir John Tenniel (1871). 
